\title{
Nigeria's development process, methodology and milestones planned for VISION 20:2020 - 13 years after
}

\author{
A private sector-led economy \\ *Hassan, M.B. ${ }^{1}$, Omobuwa, . $^{2}$
}

\begin{abstract}
A private sector led economy is the sine qua non of an egalitarian, capitalistic and welfare oriented society where every individual is free to develop and contribute to the national economy at their own pace and the individual's reward based on their productivity. However, this is only achievable where infrastructural facilities and support are optimal a situation that has been lacking in the country due to high cost of production; unfavourable business environment; lack of skilled manpower in the country; lack of adequate financial support and others. Opportunity for the government to provide a lead was adequately enunciated in the Nigeria Vision 20:2020 document but this has really not been met. This review as part of a series actually confirms this and will be a pointer to the way forward in enunciating future policy directions for the country.
\end{abstract}

*Corresponding author

Hassan, M.B.

Email: mustapha.hassan@uniosun.edu.ng

${ }^{1}$ Department of Surgery, College of Health Sciences, Osun State University, Osogbo, Nigeria.

${ }^{2}$ Department of Community Medicine, College of Health Sciences, Osun State University, Osogbo, Nigeria

Research Journal of Health Sciences subscribed to terms and conditions of Open Access publication. Articles are distributed under the terms of Creative Commons Licence (CC BY-NC-ND 4.0). (http://creativecommons.org/licences/by-nc-nd/4.0).

http://dx.doi.org/10.4314/rejhs.v9i2.9 


\section{INTRODUCTION}

A private sector-led economy is the sine qua non of an egalitarian, capitalistic and welfare oriented society where every individual is free to develop and contribute to the national economy at their own pace. Hence the reward system will be based on 'earn as you work' system where individual's benefit depends on their productivity. However, this is only achievable where infrastructural facility and support are optimal. Hence, government still has to provide a lead in kick starting a private sector led economy by providing the enabling environment and this was adequately enunciated in the Nigeria Vision 20:2020 document. But has this really been met? With just about 6 months to the end of the year 2020 , facts on the ground actually point to the opposite.

\section{Domestic and External Constraints to Growth and Development in Nigeria}

In Nigeria of today, the following factors are militating against a private sector led economy.

1. Poor and decaying infrastructure.

2. Epileptic power supply.

3. Weak fiscal and monetary policy coordination.

4. Fiscal dominance and its implications for inflation and private sector financing.

5. Pervasive rent-seeking behaviour by private and public agents, including corruption.

6. Weak institutions and regulatory deficit.

7. Policy reversals and lack of followthrough.

8. Inordinate dependence on the oil sector for government revenue/expenditure.

9. Disconnect between the financial sector and the real sector.

10. High population growth which places undue stress on basic life- sustaining resources and eventually results in diminished well-being and quality of life.

11. Insecurity of lives and property.

12. Threats of climate change, especially in relation to food production.

13. Vulnerabilities in the global economic environment, in particular, the global economic crisis and disturbances in the international oil market.

These factors have been with us since the inception of this policy documents in the year 2009. A cursory look at all sectors of Nigeria economy today indicates that these factors still subsists despite various efforts by subsequent governments to tackle them head-on.

\section{Why Nigeria Economy is still largely Government Dependent}

In Nigeria of today, government at various levels through their MDAs still remains the largest employer of labour. This is as a result of failure of the private sector in providing a leading role in the Nigeria economy. So many factors are responsible for these among which are the following.

\section{High cost of production}

The cost of production in the country is relatively high compared to neighbouring countries. Arising from the fact that most industries has to generate their electricity by themselves resulting from epileptic power supply from the national grid, hence expectedly, the cost of production will be higher. Not only that, most access road to some of this industrial estates are in a major state of disrepair with the responsible government agency not paying attention to their repair. This has increase the wear and tear attendant upon movement of goods and services from one point to the other hence increasing cost of production.

\section{Unfavourable business environment}

Arising from local factors like 'omo onile' syndrome in the southwest, militancy and oil bunkering in the Niger delta, kidnappings and banditry in the Northwest and terrorism from Boko Haram in the Northeast; all these have combined to make the business environment unfavourable for the private sector led economy. Some of the private business concerns sometimes have to relocate from their initial are of domicile to a more conducive but not necessarily productive areas thus driving up the cost of productions in most cases.

\section{Lack of skilled manpower in the country}

This has also made a private led economy virtually impossible in the country. Majority of the foreign private companies have to import their manpower in most cases thus making it difficult to develop the local content input.

\section{Lack of adequate financial support}

With the new Development Bank of Nigeria (DBN) taken off, with initial funding of US $\$ 1.3$ billion (N396.5 billion); to provide 
medium and long-term loans to MSMEs and disbursement of a total of N100 billion through the bank's 27 Participating Financial Institutions (PFIs) impacting more than 100,000 MSMEs since 2017; and 52\% of loans disbursed in 2019 meant for youths and women owned businesses; and Bank of Industry disbursing more than N400 billion in loans to large, medium, small and micro enterprises since 2016; the impact on Nigeria private sector led economy is still largely unfelt. Also taking into consideration a N5 Billion Fund for Artisanal Miners, as part of the Federal Ministry of Mines and Solid Minerals Development's Programme to boost Mining activities in Nigeria; as well as a \$20 million Fund to support young technology entrepreneurs in Nigeria; all these still remain a drop in the ocean thus accounting for the near negligible impact of these interventions.

\section{Unfavourable tax policy and over-taxation}

A lot of private enterprises are subjects to multiple taxation by various levels of government and their agencies. The improved collaboration between FIRS and the various SIRS' resulting in an increase in Nigeria's "Tax Net" (number of paying and non-paying individuals and companies in the Tax Database) from 13 million as at December 2015 to 35 million at the end of 2018, and a projected 45 million by the end of 2019 may have unwittingly led to over taxation of some of these companies thus creating an unfavourable environment for them to operate.

\section{Poor policy implementation}

A lot of favourable policies are in place to protect the private sector from the vagaries of unfavourable economic environment e.g New Whistleblowing Policy. However, poor implementation of these policies has left next to nothing impact on the private sector.

\section{CONCLUSION}

In the light of the aforementioned, it will not be far from the truth to posit that Nigeria's Vision 20:2020 as far as private sector led economy is concerned has not reached an expected favourable summit. During the period concerned, a lot of multinational corporations has had to divest from the country and relocate to neighbouring countries where the operating environment is more favourable. So many MSMEs have gone under and declared bankruptcy in view of the prevailing circumstances. And majority of Nigerians who could have been the breadwinner of their family are currently unemployed or grossly underemployed with a large percentages of the populace leaving on less than $\$ 1$ a day. There is no doubt that a paradigm shift need to occur and the country refocused on new goals possibly in line with the current thinking of SDGs.

\section{REFERENCES}

1. Nigeria Vision 20: 2020. Economic Transformation Blueprint. October 2009

2. Nigeria Vision 20: 2020. Abridged Version. December 2010

3. ECOWAS Vision 2020. Towards a democratic and prosperous community. ECOWAS commission. Abuja. 2011.

4. Femi Adesina. Buhari administration fifth anniversary factsheet: May 2020.

How to cite this article:

Hassan, M.B., Omobuwa, O. A private sector led economy. Research Journal of Health Sciences, 2021, 9(2): 182-184 